\title{
Chemopreventive Activity of Clinacanthus nutans L. Ethyl Acetate Fraction on Breast Cancer Cells Line
}

\author{
Rifki Febriansah ${ }^{1, *}$ Isna Aura Dewayanti ${ }^{2}$ \\ ${ }^{1,2}$ School of Pharmacy, Faculty of Medicine and Health Sciences, Universitas Muhammadiyah Yogyakarta, Indonesia \\ *Corresponding author, email: rifki.febriansah@umy.ac.id
}

\begin{abstract}
Cancer is a non-communicable disease, the second largest cause of death in the world. In Indonesia, breast cancer is the most common type of cancer suffered by women with 22,692 deaths case. However, chemotherapy drugs work nonselectively as it they are against both cancer cells and normal cells, which cause severe side effects. Further, a chemopreventive agent from nature needs to be developed. This study aims to determine the chemo-preventive activity of Clinacanthus nutans L. Ethyl Acetate fraction by in vitro and in silico study. By the procedure, the plant powders were macerated with ethanol $70 \%$ followed by fractionation using ethyl acetate, and thin Layer Chromatography was used to identify active compounds in it. Molecular docking was carried out using Autodock Vina for in silico study to visualize affinity between compounds and EGFR and HER-2 protein. The antioxidant test applied the DPPH method, where quercetin became the standard. The cytotoxic activity was evaluated using the MTT Assay. The results were expressed as inhibitory concentration $\left(\mathrm{IC}_{50}\right)$, and Selectivity Index (SI) was determined by calculating the ratio of the $\mathrm{IC}_{50}$ on Vero cells line and T47D cells line. The results showed that EtOAc fraction contained flavonoids. Based on molecular docking result, vitexin has stronger binding affinity with HER-2 protein than EGFR (-9.3 kcal/mol) compared to doxorubicin. The Clinacanthus nutans $\mathrm{L}$. Ethyl Acetate fraction had a weak antioxidant ability with $\mathrm{IC}_{50}$ of 576,904 $\mu \mathrm{g} / \mathrm{mL}$ while quercetin (positive control) resulted $6,874 \mu \mathrm{g} / \mathrm{mL}$. Single cytotoxic assay on Vero and T47D cell line resulted the $\mathrm{IC}_{50}$ values of $1452,835 \mu \mathrm{g} / \mathrm{mL}$ and $340,122 \mu \mathrm{g} / \mathrm{mL}$, respectively, with SI value of 4,271 . The results concluded that Clinacanthus nutans L. Ethyl Acetate Fraction is less toxic on T47D breast cancer cells line but selective on Vero normal cells line.
\end{abstract}

Keywords: Clinacanthus nutans, molecular docking, cytotoxic, T47D, Vero

\section{INTRODUCTION}

Cancer is a non-communicable disease, the second largest cause of death in the world [1]. There were 18.1 million new cases with a mortality rate of 9.6 million in 2018 [2]. Cancer is characterized by abnormal growth and spread of cells due to the overexpression of the protein. EGFR and HER-2 are the most overexpressed proteins in various cancers, including breast cancer. EGFR overexpression occurs in $15-30 \%$ of breast cancers and HER-2 overexpression occurs in 20-30\% of breast cancers [3].

Some cancer therapy includes surgery, radiation, and chemotherapy. Chemotherapy is a treatment by administering drugs that can inhibit or kill cancer cells [4]. Chemotherapy drugs have a mechanism by attacking cells as a whole, both cancer cells and normal cells [5]. When chemotherapy damages normal cells, this will cause side effects [6]. Therefore, the development and discovery of cancer treatments, especially breast cancer, that is appropriate and safe need to be continued.

Herbal plants in Indonesia are known to have benefits for a variety of diseases, and one of them is Dandang Gendis herbs (Clinacanthus nutans L.). Based on a previous study, Dandang Gendis is known to be anti-inflammatory [7], antidiabetic [8], and antihyperglycemic [9]. Clinacanthus nutans contains flavonoids such as vitexin, isovitexin, shaftoside, isomolupentin 7-Oß-glucopyranoside, orientin, and isoorientin [10]. Vitexin is one of the most compounds contained in the Clinacanthus nutans ethyl acetate extract [11]. Also, Clinacanthus nutans ethyl acetate extract is known to have antioxidant and cytotoxic activity against HeLa cancer cells [12]. Thus, in a more specific extract, ethyl acetate fraction, the vitexin compound in Clinacanthus nutans L., is thought to play a role in the chemo-preventive activity.

This study aims to determine the chemo-preventive activity of Clinacanthus nutans L. Ethyl Acetate (EtOAc) fraction against the T47D breast cancer cells line. The preliminary test with TLC to identify compounds in the EtOAc Fraction was followed by in silico test using the Molecular Docking method on EGFR and HER-2 protein cancer cells. Then, antioxidant test applied the DPPH method. Cytotoxic test of the EtOAc Fraction was analyzed using the MTT Assay method on T47D breast cancer cells line and Vero normal cells line. Also, the selectivity test was determined by calculating the selectivity index. This 
research is expected to support the development of new medicines from natural basis as a chemopreventive agent.

\section{MATERIALS AND METHODS}

\subsection{Plant material}

Dandang Gendis (Clinacanthus nutans L.) plants were obtained from Bantul, Yogyakarta, and was determined in Biology Laboratory, Faculty of Science, Universitas Ahmad Dahlan, Yogyakarta.

\subsection{Extraction and fractination}

Clinacanthus nutans L. powder was macerated using ethanol $70 \%$ solvent in a ratio of 1:10 for 5 days, and was re-macerated for 2 days. The extracts were then fractionated with ethyl acetate solvent in a ratio of 1:1. The results of the ethyl acetate fraction were concentrated using a rotary evaporator at $60^{\circ} \mathrm{C}$ with a speed of $100 \mathrm{rpm}$.

\subsection{Phytochemistry compound analysis by Thin Layer Chromatography (TLC)}

The flavonoid compounds in EtOAc fraction was identified through TLC using the silica gel $\mathrm{GF}_{254}$ plate and the mobile phase containing ethyl acetate, formic acid, acetate acid and water with a ratio of 100:11:11:26. The plate was observed under UV light with wavelengths of $254 \mathrm{~nm}$ and $366 \mathrm{~nm}$. With this observation, the spot was seen due to sample elution on the plate. Then the elution distance was measured, and the respective $\mathrm{Rf}$ value was calculated.

\subsection{Molecular docking with Autodock Vina}

Molecular Docking is a computational test used as a preliminary test to know the binding affinity between ligand (compounds) and receptor (protein target). In this study, molecular docking begun by downloading the Autodock Vina application and several supporting applications. The EGFR and HER2 structures are downloaded from the Protein Data Bank (PDP) (www.rcsb.org) with ID 1M17 and 3PP0. Proteins and ligands were prepared using the DS Visualizer application. The proteins were saved as ' $1 \mathrm{~m} 17 . p p d b$ ' and ' $3 p p 0 . p d b$ ' while the original ligand was saved as 'ligand.pdb'. Then the 'pdb' file format got converted to 'pdbqt' by using the Autodock Tools application. Before running the docking function, the $1 \mathrm{~m} 17 . \mathrm{pdbqt}$, 3 pp0.pdbqt, and ligand.pdbqt files were put in the same folder. A new text file was created and named 'conf.txt'. The conf.txt file contained information related to the docking process. To determine the RMSD value, a conformation with an RMSD value of less than $2 \AA$ was selected. Visualization of docking results was to see the affinity between EGFR and HER2, and the target cell can be done with the DS Visualizer application.

\subsection{Antioxidant test by DPPH radical scavening assay}

The DPPH $0.4 \mathrm{mM}$ standard solution was prepared as much as $15.8 \mathrm{mg}$ and dissolved in methanol up to 25 $\mathrm{mL}$. Then, a 10-mL DPPH solution was taken, $100-\mathrm{mL}$ methanol was added, and homogeneous used vortex. The solution of EtOAc Fraction and quercetin as a comparator were prepared, and several concentrations were made. Antioxidant test applied the DPPH method (1,1-diphenyl-2-picrylhydrazyl) by taking $2 \mathrm{ml}$ of the EtOAc fraction and quercetin solution of each concentration, then adding it with $2 \mathrm{ml}$ of DPPH 0,4 mM and $6 \mathrm{~mL}$ methanol. Homogeneous using vortex were let to stand for operating time. The absorbance of the sample was read at the maximum wavelength of $\mathrm{DPPH}$, and then the $\mathrm{IC}_{50}$ value was calculated.

\subsection{Cytotoxic test by MTT assay}

The solution of EtOAc Fraction of $10^{5} \mu \mathrm{g} / \mathrm{mL}$ was prepared, and several series concentrations were made. Cells with a density of $1 \times 10^{4}$ cells/well were distributed into 96 well plates and incubated for 48 hours to adapt and let stuck to the bottom of the well. After that, the medium was taken, washed with PBS, and added with $100 \mu \mathrm{L}$ culture medium containing only $0.2 \%$ DMSO (control) or EtOAc Fraction. Culture medium containing the sample was removed and washed with $100 \mu \mathrm{L}$ PBS. Each well was then added with $100 \mu \mathrm{L}$ culture medium containing $5 \mathrm{mg} / \mathrm{ml} \mathrm{MTT}$, and they were incubated again for 4 hours at $37^{\circ} \mathrm{C}$. Living cells reacted with MTT to form purple formazan crystals. After 4 hours, the medium containing MTT was removed, washed PBS, and added with an SDS stopper solution in $0.1 \% \mathrm{HCl}$ $200 \mu \mathrm{L}$ to dissolve the formazan crystals. It was rocked over a shaker for 10 minutes, and read with an ELISA reader at a $595 \mathrm{~nm}$ wavelength. The absorption value was converted into live cell $\%$, and $\mathrm{IC}_{50}$ was calculated with a linear regression equation.

\subsection{Selectivity test by SI calculation}

Selectivity test was determined using the SI (Selectivity Index) parameter with formula:

$$
\mathrm{SI}=\frac{\mathrm{IC}_{50} \text { normal cell }}{\mathrm{IC}_{50} \text { cancer cell }} \times 100 \%
$$

Samples are said to have a high selectivity if the SI value is $\geq 3$, and samples said to be less selective if the SI value is $<3$ [13].

\section{RESULTS AND DISCUSSION}

\subsection{Extraction and fractionation}

A total of $1 \mathrm{~kg}$ of plant dried powders were macerated using 7 liters of $70 \%$ ethanol solvent which

produced 4,700-mL liquid extract. Then it was fractionated using ethyl acetate solvent which later produced 2,800 mL of ethyl acetate (EtOAc) fraction. 
Ethyl acetate is a semipolar solvent that can attract flavonoids, secondary metabolites in plants [14]. This process resulted in 10.4 grams of EtOAc Fraction extract. EtOAc Fraction of Clinacanthus nutans yielded of $1,04 \%$.

\subsection{Phytochemistry compound analysis by TLC}

Based on a previous study, Clinacanthus nutans L. contains flavonoids including vitexin, isovitexin, shaftoside, isomolupentin 7-Oß-glucopyranoside, orientin, and isoorientin [10]. The identification of flavonoid compounds contained in EtOAc Fraction was carried out using Thin Layer Chromatography (TLC) with the principle of separation based on polarity. The mobile phase was in the form of solvents with a multilevel polarity that used ethyl acetate : formic acid : acetic acid : water (ratio 100: 11: 11: 27), which has shown good results on the separation of compounds contained in Clinacanthus nutans [15]. According to Markham (1988), flavonoids cause a reduction of fluorescence at UV $254 \mathrm{~nm}$, whereas at UV $366 \mathrm{~nm}$ flavonoids have yellow, blue, or green fluorescence and spot of glycoside flavonoids appear dark purple [16]. Based on TLC test, EtOAc Fraction's dark purple spots that fluorescence under UV $254 \mathrm{~nm}$ and UV $366 \mathrm{~nm}$ contained flavonoid compounds in spot number 2 with Rf value 0.66 . The $\mathrm{Rf}$ value has the same profile as the vitexin standard used in research conducted by [15]. The data interpretation of the flavonoid compounds can be seen in figure 1 and table 1.
Table 1. Thin Layer Chromatography (TLC) result

\begin{tabular}{lllll}
\hline \multirow{2}{*}{ Number } & \multirow{2}{*}{$\begin{array}{l}\text { Sf } \\
\text { Value }\end{array}$} & Visible & UV 254 & UV 366 \\
\cline { 3 - 5 } & 0,81 & - & Green & - \\
2 & 0,66 & Dark & Green & Dark \\
& & yellow & & purple \\
3 & 0,50 & Dark & Dark & - \\
& & yellow & purple & \\
4 & 0,25 & - & Dark & - \\
& & & purple & \\
\hline
\end{tabular}

\subsection{Molecular docking with Autodock Vina}

Molecular docking as a preliminary test was done using Autodock Vina to know the binding affinity between vitexin, a compound contained in Clinacanthus nutans, and the target protein. The target proteins used were EGFR and HER-2 with Doxorubicin used as a comparison. The parameters were RMSD value and docking score. A molecule has a good affinity if it has a low docking score with an RMSD value of <2 $\AA$ [17]. The results of molecular docking on the EGFR target protein showed that vitexin $(-8.5 \mathrm{kcal} / \mathrm{mol}) \mathrm{had}$ a higher docking score than doxorubicin $(-10.0 \mathrm{kcal} / \mathrm{mol})$ (table 2). This can be interpreted that vitexin has an energy affinity that is not lower than doxorubicin so that it

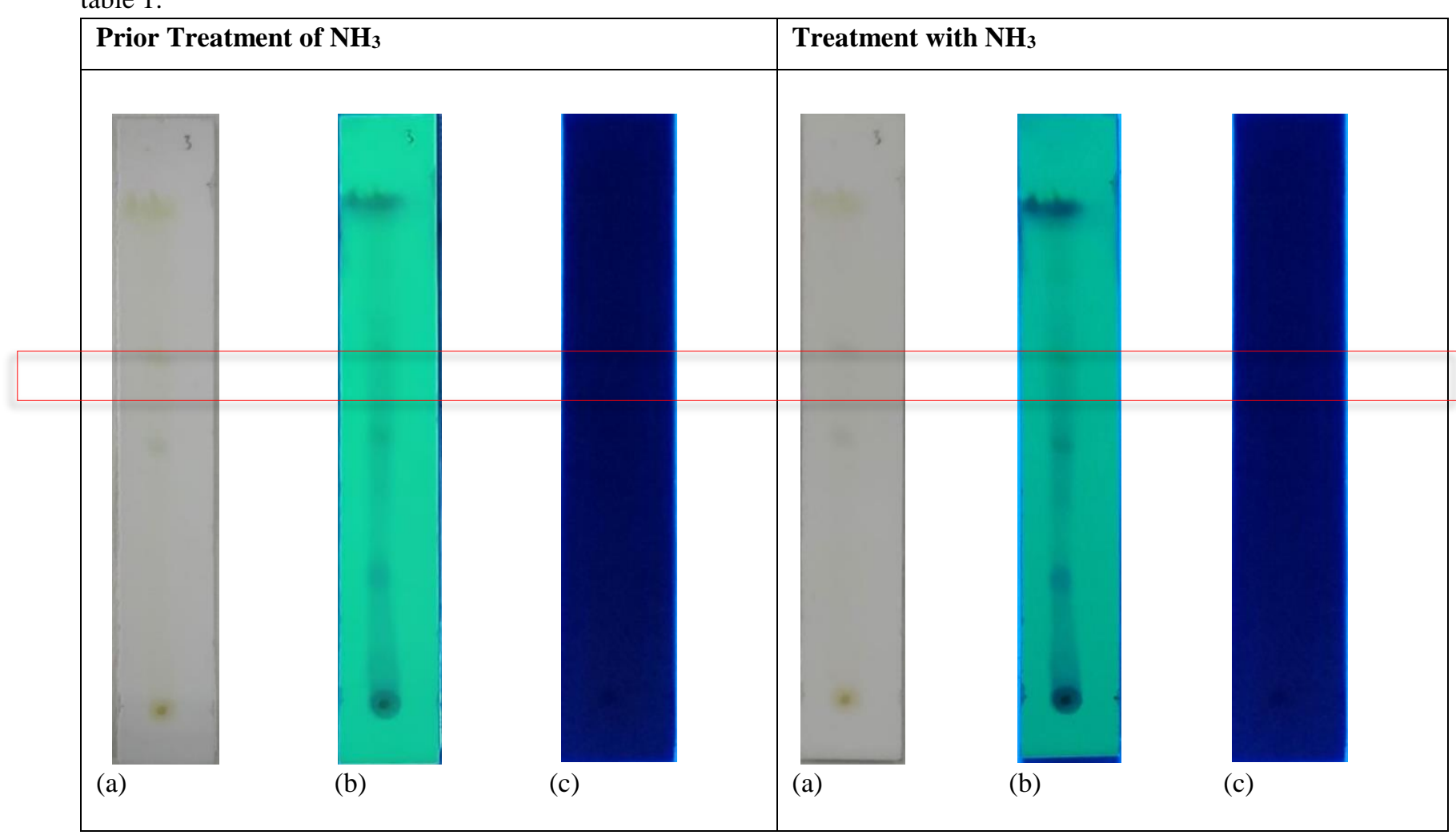

Figure 1. Thin Layer Chromatography (TLC) profile (a) visible (b) UV 254 nm (c) UV 366 nm 
would not bind with EGFR protein as strong as doxorubicin. In contrast, the results of molecular docking on the HER-2 target protein showed that vitexin $(-9.3 \mathrm{kcal} / \mathrm{mol})$ had a lower docking score than doxorubicin $(-7.0 \mathrm{kcal} / \mathrm{mol})$ as seen in table 2 . This can be interpreted that vitexin has lower affinity energy than doxorubicin so that its bond with HER-2 protein is stronger than doxorubicin. Based on these results, the vitexin compound has a stronger and more stable binding affinity with HER-2 protein rather than the EGFR with doxorubicin. The visualization of molecular docking can be seen in Figure 2.
Table 2. Molecular docking result in target protein

\begin{tabular}{lllll}
\hline Protein & Compounds & $\begin{array}{l}\text { Confor- } \\
\text { mation }\end{array}$ & $\begin{array}{l}\text { RMSD } \\
\text { Value }\end{array}$ & $\begin{array}{l}\text { Docking } \\
\text { Score }\end{array}$ \\
\hline \multirow{2}{*}{ EGFR } & Vitexin & 4 & 1,872 & $-8,5$ \\
& Doxorubicin & 2 & 1,141 & $-10,0$ \\
\hline \multirow{2}{*}{ HER2 } & Vitexin & 2 & 1,306 & $-9,3$ \\
& Doxorubicin & 2 & 1,619 & $-7,0$ \\
\hline
\end{tabular}

Figure 2. Docking visualization in target protein

Compounds




\subsection{Antioxidant test by DPPH radical scavenging assay}

The antioxidant test was done by DPPH free radicals (1,1-diphenyl-2-picrylhydrazyl) method. Free radicals that are produced continuously in the body will disrupt DNA, which can lead to cell mutations as the onset of cancer [18]. Antioxidants are molecules that can inhibit the oxidation of a molecule that can produce these free radicals [19]. Antioxidant compounds will donate hydrogen atoms to DPPH free radicals so that it becomes a non-radical reduced form. The antioxidant activity is characterized by a decrease in the intensity of the deep purple to yellow [20].

In this process of the study, the color change was observed in the form of decreased DPPH absorbance measured with a UV-Vis spectrophotometer. The percentage of EtOAc Fraction inhibition showed an upward trend with increasing concentration. Based on the graph of the relationship between the percentage of inhibition with concentration, the linear regression equation $\mathrm{y}=0.0504 \mathrm{x}+20.924\left(\mathrm{R}^{2}=0.9347\right)$ was used for the $\mathrm{IC}_{50}$ calculation (Figure 4). The test results showed that EtOAc Fraction had a weak antioxidant activity with an $\mathrm{IC}_{50}$ value of $576,904 \mu \mathrm{g} / \mathrm{mL}$. In this study, quercetin was used as a comparison. Quercetin is a flavonoid that is often found in plants and is known to have various biological activities, especially antioxidants [21]. The test for quercetin showed that it had a very strong antioxidant activity with an $\mathrm{IC}_{50}$ value of $6.874 \mu \mathrm{g} / \mathrm{mL}$ (Table 4) (Figure 4). These results are appropriate with the previous study conducted by Rahayu (2009) pointing out that quercetin has an $\mathrm{IC}_{50}$ value of $6.28 \mu \mathrm{g} / \mathrm{mL}$ [22]. A very strong antioxidant activity in quercetin possibly happened because the comparison used in this study was pure quercetin powder while EtOAc Fraction consisted of various secondary metabolites, so it has weak antioxidant activity

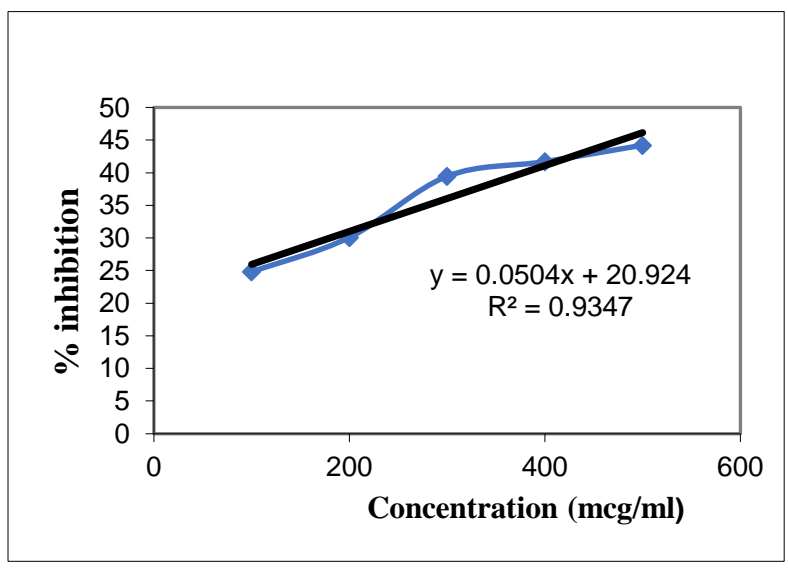

Figure 3. EtOAc Fraction inhibition curve
Table 4. The \% inhibition persentation of EtOAc

Fraction treatment

\begin{tabular}{crrrr}
\hline $\begin{array}{c}\text { Concentration } \\
(\boldsymbol{\mu g} / \mathbf{m L})\end{array}$ & $\begin{array}{c}\text { Absorbance } \\
\text { Average }\end{array}$ & $\begin{array}{c}\text { Standard } \\
\text { Deviation }\end{array}$ & $\begin{array}{c}\text { Blanko } \\
\text { Absorbance }\end{array}$ & $\begin{array}{c}\% \\
\text { Inhibition }\end{array}$ \\
\hline 100 & 0,6281 & 0,0595 & 0,8353 & 24,8094 \\
200 & 0,5839 & 0,0159 & 0,8353 & 30,0930 \\
300 & 0,5057 & 0,0608 & 0,8353 & 39,4549 \\
& & & & \\
400 & 0,4870 & 0,0543 & 0,8353 & 41,7016 \\
500 & 0,4659 & 0,0184 & 0,8353 & 44,2276 \\
\hline
\end{tabular}

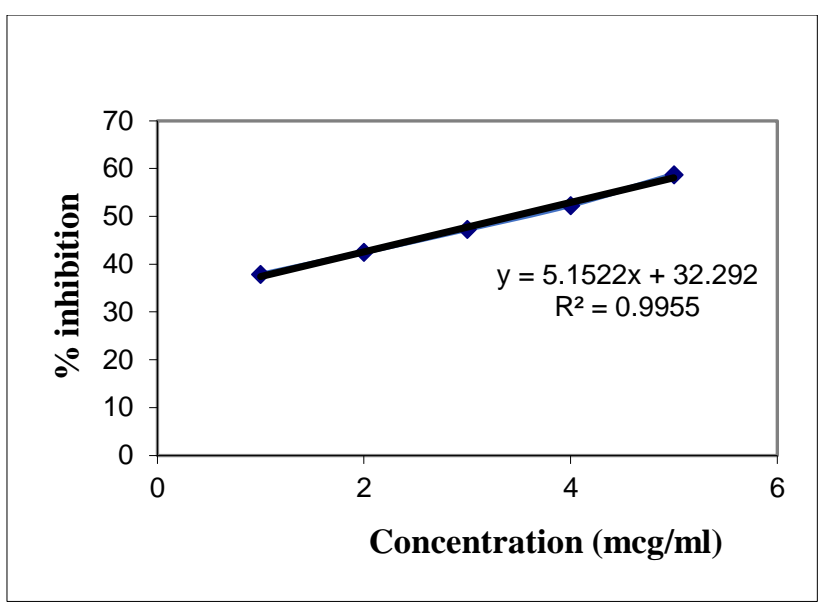

Figure 4. Quersetin inhibition curve

Table 5. The \% inhibition persentation of Quersetin treatment

\begin{tabular}{crrrr}
\hline $\begin{array}{c}\text { Concentration } \\
(\boldsymbol{\mu g} / \mathbf{m L})\end{array}$ & $\begin{array}{c}\text { Absorbance } \\
\text { Average }\end{array}$ & $\begin{array}{c}\text { Standard } \\
\text { Deviation }\end{array}$ & $\begin{array}{c}\text { Blanko } \\
\text { Absorbance }\end{array}$ & $\begin{array}{c}\% \\
\text { Inhibition }\end{array}$ \\
\hline 2 & 0,5190 & 0,0115 & 0,8353 & 37,8706 \\
4 & 0,4802 & 0,0282 & 0,8353 & 42,5157 \\
6 & 0,4401 & 0,0063 & 0,8353 & 47,3123 \\
8 & 0,3983 & 0,0168 & 0,8353 & 52,3125 \\
10 & 0,3447 & 0,0180 & 0,8353 & 58,7334 \\
\hline
\end{tabular}




\subsection{Cytotoxic test by MTT assay}

The cytotoxic test was conducted to determine the activity of EtOAc Fraction in inhibiting the growth of T47D breast cancer cells and Vero normal cells. The cytotoxic parameter used was the ability to convert MTT substrates into purple formazan crystals by the dehydrogenase enzyme in living cells. The intensity of the purple color is proportional to the number of living cells. If the intensity of the purple color is greater, the number of living cells will increase. The results of the cytotoxic test study showed that EtOAc Fraction was quite toxic in inhibiting the growth of T47D cancer cells with $\mathrm{IC}_{50}$ of $340.122 \mu \mathrm{g} / \mathrm{mL}$. At the lowest concentration of $31.25 \mu \mathrm{g} / \mathrm{mL}$, the viability of living cells was $78.25 \%$. That could mean that EtOAc Fraction could only kill

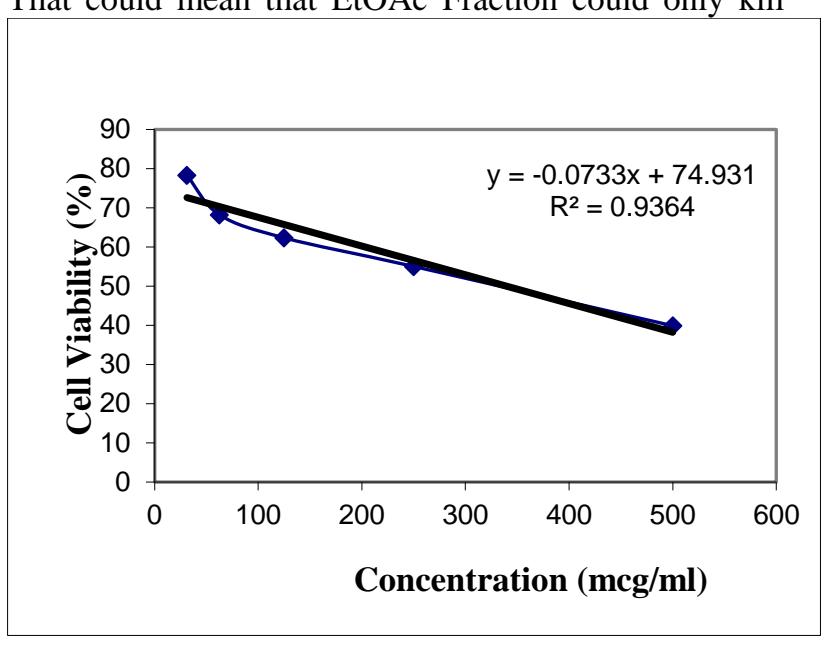

Figure 5. Single EtOAc Fraction cytotoxic effects curve on T47D cancer cells line
$21.75 \%$ of T47D cells $(100-78.25 \%)$. Whereas at the highest concentration of $500 \mu \mathrm{g} / \mathrm{mL}$, the viability of living cells was $39.84 \%$, which means that EtOAc Fraction can kill more T47D cells with a percentage of $60.16 \%$ (Figure 5).

Based on these results, there was a decrease in the viability of T47D living cells in line with the increase of EtOAc Fraction concentrations. In the results of cytotoxic tests on normal Vero cells, EtOAc Fraction was proven to be non-toxic in inhibiting the growth of Vero cells with $\mathrm{IC}_{50}$ of $1452,835 \mu \mathrm{g} / \mathrm{mL}$ (Figure 6).

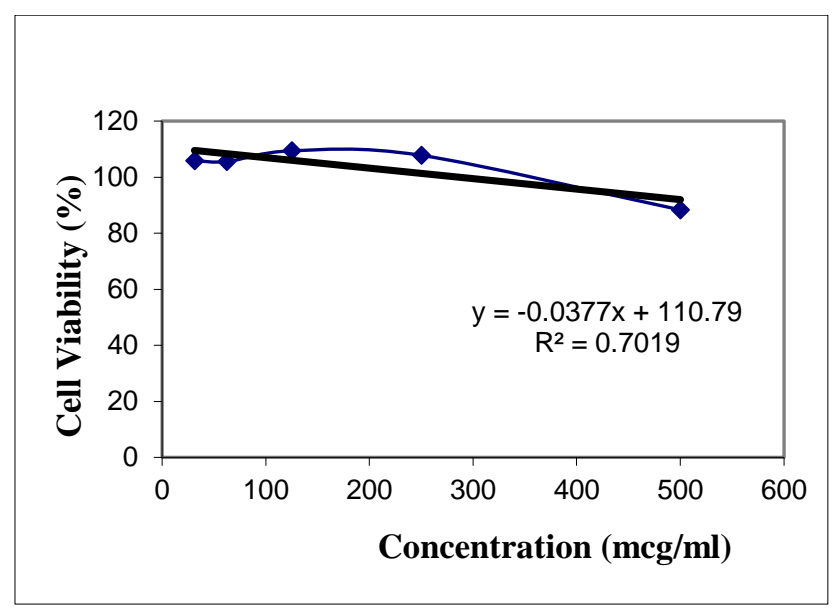

Figure 6. Single EtOAc Fraction cytotoxic effects curve on Vero cancer cells line

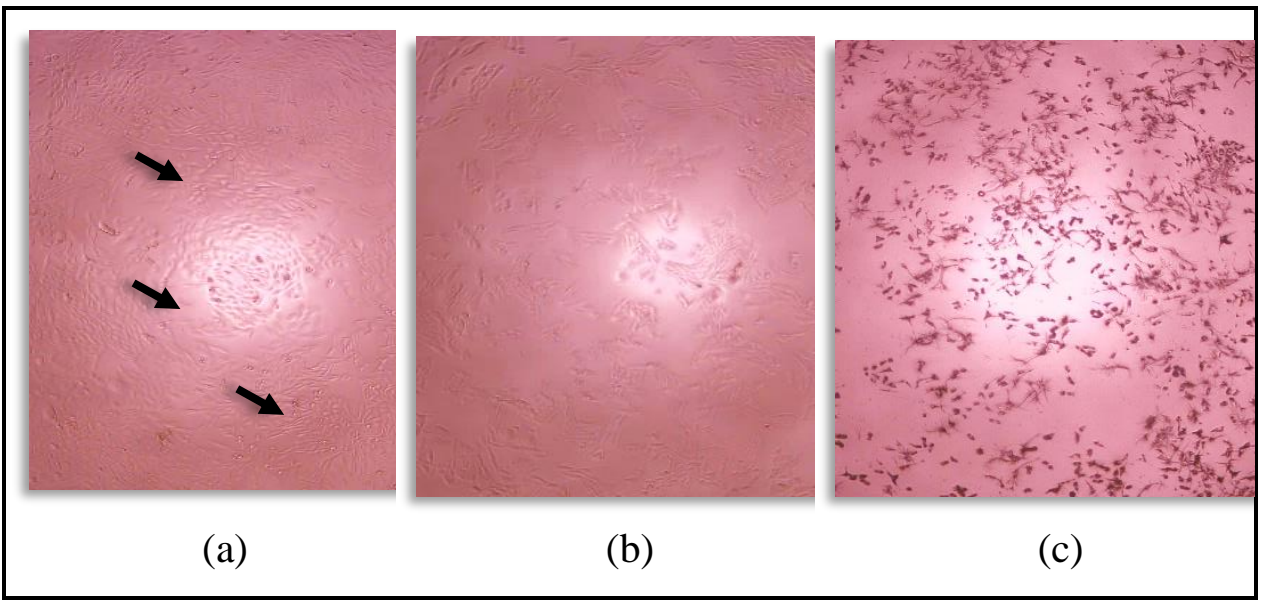

Figure 7. An overview of T47D cell morphology under an inverted microscope (a) before being treated with a sample (b) after being treated with a sample (c) after being treated with MTT reagen. The black arrow ( ) shows cells undergoing morphological changes. 


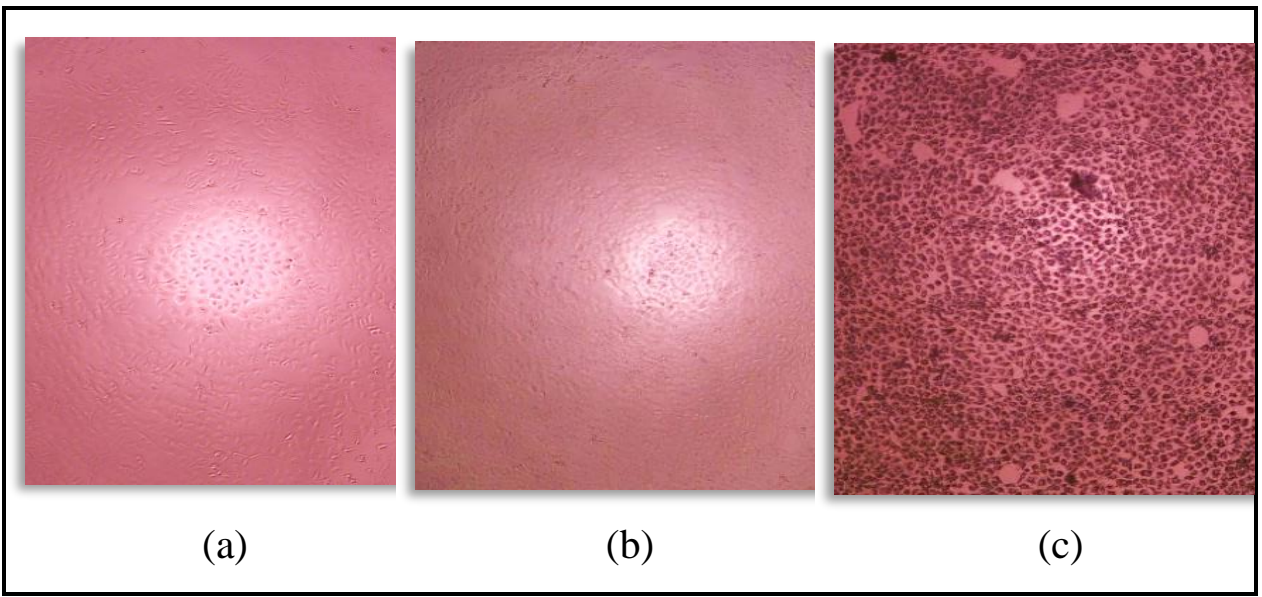

Figure 8. An overview of Vero cell morphology under an inverted microscope (a) before being treated with a sample (b) after being treated with a sample (c) after being treated with MTT reagen. The black arrow ( $\mathbf{Y}$ ) shows cells undergoing morphological changes

In addition to quantitative analysis, cell morphology observations were also carried out using an inverted microscope to determine changes in cell morphology before and after being treated. T47D cells did undergo morphological changes that were originally long-oval, before being treated with EtOAc Fraction, to become round and irregular after being treated (Figure 7). Changes in cells' shape morphology were also clearly seen in Vero cells, which were originally slightly-oval round shape to round shape with smaller size (Figure 8). Cytotoxic test results showed that the EtOAc Fraction was quite toxic against T47D cancer cells.

\subsection{Selectivity test by SI calculation}

Selectivity test is important because chemotherapy drugs have a mechanism by attacking cells as a whole, both cancer cells and normal cells [5]. Anticancer agents should be able to kill cancer cells without harming normal cells [23]. By calculating Selectivity Index (SI), the ability of EtOAc Fraction as a chemopreventive agent to attack only cancer cells can be determined. SI was calculated by comparing $\mathrm{IC}_{50}$ of Vero normal cells with $\mathrm{IC}_{50}$ of $\mathrm{T} 47 \mathrm{D}$ cancer cells. The calculation requirements for $\mathrm{SI}$ are the $\mathrm{IC}_{50}$ values of cancer cells in cytotoxic tests of not more than $1000 \mu \mathrm{g} / \mathrm{mL}$ [24]. In this study, the $\mathrm{IC}_{50}$ value of T47D cancer cells was 340.122 $\mu \mathrm{g} / \mathrm{mL}$, so it was accordant to the SI calculation requirements. It is said to be selective if the SI value $\geq 3$ [13]. The calculation results showed that EtOAc Fraction was selective against T47D cells with SI of 4,271 (Table 6).

Table 6. Selectivity Index (SI) value

\begin{tabular}{ccc}
\hline Cell Target & IC $_{50}$ Value & SI Value \\
\hline T47D Breast & 340,122 & \\
Cancer Cell & 1452,835 & 4,271 \\
Vero Normal Cell & \\
\hline
\end{tabular}

\section{CONCLUSION}

Clinacanthus nutans L. ethyl acetate (EtOAc) fraction contains a flavonoid compound. One of the flavonoid compounds is in the form of vitexin which has better activity in inhibiting the expression of HER-2 protein than EGFR protein compared to Doxorubicin. The EtOAc Fraction has a weak antioxidant ability. Cytotoxic test results showed a weak toxicity with a selectivity index of 4.740 , indicating that Clinacanthus nutans $\mathrm{L}$. ethyl acetate fraction is less toxic against T47D breast cancer cells but selective against Vero normal cells. Thus, it needs more studies to develop as a chemopreventive agent, especially in breast cancer.

\section{AUTHOR'S CONTRIBUTION}

Rifki Febriansah (RF) has contributed for the concept of the research and analysis the data. Isna Aura Dewayanti (IAD) has contributed for doing the research.

\section{ACKNOWLEDGMENTS}

The gratitude of the researcher is conveyed to Anticancer Research Team, School of Pharmacy, Universitas Muhamamadiyah Yogyakarta, for the support so this research was well done. We also would like to thanks to LP3M UMY for funding this research.

\section{REFERENCES}

[1] World Health Organization. 2018. Breast cancer: Early diagnosis and screening. World Health Organization.

http://www.who.int/cancer/prevention/diagnosiss creening/breast-cancer/en/- Diakses 29 September 2020 .

[2] Globocan. 2012. Coloretal cancer incidence and mortality worldwide in 2012. Diakses pada $5 \mathrm{Mei}$ 2020.

from: 
http://globocan.iarc.fr/old/FactSheets/cancers/col orectal-new.asp

[3] Hsu, Jennifer., Hung Mien-Chie. 2016. The Role of HER2, EGFR, and Other Receptor Tyrosine Kinases in Breast Cancer. Cancer Metastasis Rev. 2017 December 01.

[4] Remesh, A. 2012. Toxicities of Anticancer Drugs and Its Management. International Journal of Basic \& Clinical Pharmacology.

[5] Sutejo, I.R., Putri, H., Meiyanto, E. 2016. Selektivitas Ekstrak Etanolik Buah Makassar (Brucea javanica) pada Kanker Payudara Metastasis secara In Vitro. Journal of Agromedicine and Medical Sciences. Vol. 2 (1).

[6] Patel, D., Jyoti. 2018. Managing Side Effect of Chemotherapy Cancer.

[7] Nasution, Anna Leli. 2010. Perbandingan Efek Antiinflamasi Fraksi Etilasetat Daun Dandang Gendis (Clinacanthus nutans (Burm.f.) Lindau) Bentuk Suspensi Dan Yang Diperangkapkan Dalam Matriks Nata De Coco. Skripsi. Universitas Sumatera Utara.

[8] Deni Rahmat, 2015. Uji Aktivitas Penghambatan i-Glukosidase secara In Vitro Pemeriksaan Mutu Ekstrak dan Nanopartikel Ekstrak Etanol 70\% Daun Dandang Gendis (Clinacanthus nutans Lindau). Skripsi. Jakarta: Universitas Pancasila.

[9] Saputri, Silviana Cahya. 2016. Uji Aktivitas Antihiperglikemik Ekstrak Daun Dandang Dendis (Clinacantus nutans Lindau). Skripsi. Semarang: Jurusan Kimia FMIPA, Universitas Negeri Semarang.

[10] Teshima, I., et al. 1997. Sulfur-containing Glucosides from Clinacanthus nutans. Phytochemistry. 48: 831-835.

[11] Chelyn, J. L., Omar, M, Yousof, N.S., Ranggasamy R., Wasiman, M.I., Ismail, Z. 2014. Analysis of Flavone C-Glycosides in the Leaves of Clinacanthus nutans (Burm. f.) Lindau by HPTLC and HPLC-UV/DAD. The Scientist World Journal. Vol 2014.

[12] Arullapan, Sangeetha et al., 2014. In Vitro Screening of Cytotoxic, Antimicrobial and Antioxidant Activities of Clinacanthus nutans (Acanthaceae) leaf extracts. Tropical Journal of Pharmaceutical Research. September 2014. 13(9): 1455-1461.

[13] Machana, Sasipawan., Weerapreeyalld., Natthida. 2011. Cytotoxic and Apoptotic Effects of Sic Herbal Plants Against the Human
Hepatocarcinoma (HepG2) Cell Line. Biomed Central. Vol. 6 (39).

[14] Harborne, JB. 1996. Metode Fitokimia: Penuntun Cara Modern Menganalisa Tumbuhan. Terbitan Kedua. Diterjemahkan oleh Padmawinata, K. \& Sudiro, I. Bandung: ITB Press.

[15] Chelyn, J. L., Omar, M, Yousof, N.S., Ranggasamy R., Wasiman, M.I., Ismail, Z. 2014. Analysis of Flavone C-Glycosides in the Leaves of Clinacanthus nutans (Burm. f.) Lindau by HPTLC and HPLC-UV/DAD. The Scientist World Journal. Vol 2014.

[16] Markham, K. R. 1988. Cara Mengidentifikasi Flavonoid. Diterjemahkan oleh Padmawinata. K. Bandung: ITB Press.

[17] Purnomo, H., 2011, Kimia Komputasi, Molecular Docking PLANTS, Penambatan Molekul PLANTS (Protein Ligand Ant System), Pustaka Pelajar, Yogyakarta.

[18] Astuti, Y. N. 2009. Uji Aktivitas Penangkap Radikal DPPH oleh Analog Kurkumin Monoketon dan N-Heteroalifatik Monoketon. Surakarta: Universitas Muhammadiyah Surakarta.

[19] Rajnarayana, K., Ajitha M., Gopireddy G., dan Giriprasad, V. 2011. Comperative antioxidant potential of some fruit and vegetables using DPPH method. International Journal of Pharmacy \& Technology. Vol. 3 (1), 1952-1957.

[20] Molyneux, Philip. 2004. The Use of The Stable Free Radical Diphenylpicrylhydrazyl (DPPH) for Estimating Antioxidant Activity. Songklanakarin Journal Sciences Technology. Vol. 26 (2), 211 219.

[21] Orak, H.H, 2006, Total Antioxidant Activities, Phenolic, Anthocyanins, Polyphenoloxidase Activities In Red Grape Varieties, Electronic Journal of Polish Agricultural University Food Science and Technology, 9.

[22] Rahayu, S. 2009. Penentuan Aktivitas Antioksidan dari Ekstrak Etanol Daun Ketapang (Terminalia catapa L.) dengan Metode 1,1-difenil-2pikrilhidarzil. Tugas Akhir. Semarang: Jurusan Kimia FMIPA Universitas Diponegoro.

[23] Nurani, Laela. 2016. Cytotoxicity and Antiproliferative Test on T47D and Vero Cell Lines of Nigella Sativa L. Seed. Jurnal Ilmiah Kefarmasian. Vol. 2 (1).

[24] Omoregie ES, and Sisodia BS. 2012. In Vitroantiplasmodial Activity and Cytotoxicity of Leaf extracts of Jatropha Tanjorensis J.L. Ellis and Soroja. Bajopas, 5(1): 90-97. 